九州大学学術情報リポジトリ

Kyushu University Institutional Repository

Time-series measurements of the colored volcanic vent seawaters during a tidal cycle in Nagahama Bay, Satsuma Iwo-jima Island, Kagoshima, Japan

Ninomiya, Tomomi

Department of Earth and Planetary Sciences, Graduate School of Sciences, Kyushu University

Kiyokawa, Shoichi

Department of Earth and Planetary Sciences, Graduate School of Sciences, Kyushu University

https://doi.org/10.5109/13524

出版情報: 九州大学大学院理学研究院紀要 : Series D, Earth and planetary sciences. 32 (2), pp.114, 2009-03-02. Faculty of Science, Kyushu University

バージョン :

権利関係 : 
Mem. Fac. Sci., Kyushu Univ., Ser. D, Earth \& Planet. Sci., Vol. XXXII, No. 2, pp. 1-14, March 2, 2009

\title{
Time-series measurements of the colored volcanic vent seawaters during a tidal cycle in Nagahama Bay, Satsuma Iwo-jima Island, Kagoshima, Japan
}

\author{
Tomomi Ninomiya ${ }^{*}$ and Shoichi Kiyokawa*
}

\begin{abstract}
Satsuma Iwo-jima Island, located $40 \mathrm{~km}$ south of Kyushu Island, Japan, bears a shallow-water hydrothermal system. The coastal seawaters are stained ivory and red colors attributing to the presence of suspended aluminous and ferric precipitates produced by the mixing of volcanic fluids and seawaters. In Nagahama Bay, which is partly isolated from the pelagic realm, the seawaters appear dark reddish brown, attributing to the concentrated ferric precipitatess. In order to understand how the ferric precipitates behave, we focused on characterizing the relationship between the ferric precipitates and the diurnal tidal cycle in the bay. Using a multiple sensor, we measured the seawaters from the surface to the bottom of the bay for two weeks, in order to sample one complete tidal cycle, the spring and neap tides in 2007 . We accumulated data on $\mathrm{pH}$, depth, and turbidity. The reddish brown waters exhibited both daily and lunar cycle changes in turbidity corresponding to the tidal inflow of pelagic seawaters. The waters lost ferric precipitates during the high tide within a day, and during the spring tide when there was a major difference in sea level between high and low tides. During under an influence a Typhoon passing through the region, however, the waters appeared significantly cloudier with suspended particles than on normal days due to sediment re-suspension.
\end{abstract}

Keywords: Shallow-water hydrothermal system, Satsuma Iwo-jima Island, ferric precipitates, tidal cycle, volcanic fluids

\section{Introduction}

Shallow-water hydrothermal systems, which are usually related to coastal volcanism, are present in twenty one regions around the world (Tarasov et al., 2005). They often bear discolored seawaters around their volcanic vent areas. In Matupi Harbor, Papua New Guinea, which has the maximum depth of $64 \mathrm{~m}$, there is pronounced stratification of the waters developed due to the inflow of heated volcanic fluids, which is the most evident in the uppermost three meters of water (Tarasov et al., 1999). Satsuma Iwo-jima Island is one of the best places to observe a shallow-water hydrothermal system with reddish brown and ivory colored seawaters. Nagahama Bay, which is a partly closed bay of the island, bears reddish seawaters with abundant suspended particles of iron oxide (Kamada, 1964).

* Manuscript received on 8 December 2008; accepted on 15 December 2008

Department of Earth \& Planetary Sciences, Graduate School of Sciences, Kyushu University, 610-1 Hakozaki, Higashiku, Fukuoka 812-8581, JAPAN; Corresponding author's e-mal: kiyokawa@geo.kushu-u.ac.jp 
Within the bay, however, it is difficult to directly observe color differences in the surface waters, because that most of the bay surface exhibits cloudy reddish waters almost all the time. In this study, in which we measure seawaters from the surface to the bottom of Nagahama Bay, Satsuma Iwo-jima Island, we reveal the relationship between the reddish ferric precipitations in the bay water and pelagic waters due to the tidal activity.

\section{Geological Setting}

Satsuma Iwo-jima Island, which has one of the most active volcanoes in Japan, is located about $40 \mathrm{~km}$ south of the southern coast of Kyushu Island (Fig. 1). It is situated along the northwestern rim of Kikai Caldera (Matsumoto, 1943), which last erupted 6500 years ago. This island extends $5.5 \mathrm{~km}$ wide from the east to west and $4 \mathrm{~km}$ long from the north to south. About $2 \mathrm{~km}$ east of Satsuma Iwojima island, there is another small volcanic island called "Showa Iwo-jima Island" which was formed by a submarine eruption of rhyolitic lava in 1934 within the Satsuma Iwo-jima caldera. In Satsuma Iwo-jima Island, there are two post-caldera volcanoes which are the rhyolitic dome "Iwodake" and the basaltic cone "Inamura-dake" (Ono et al., 1982). The latest magmatic eruption of Iwo-

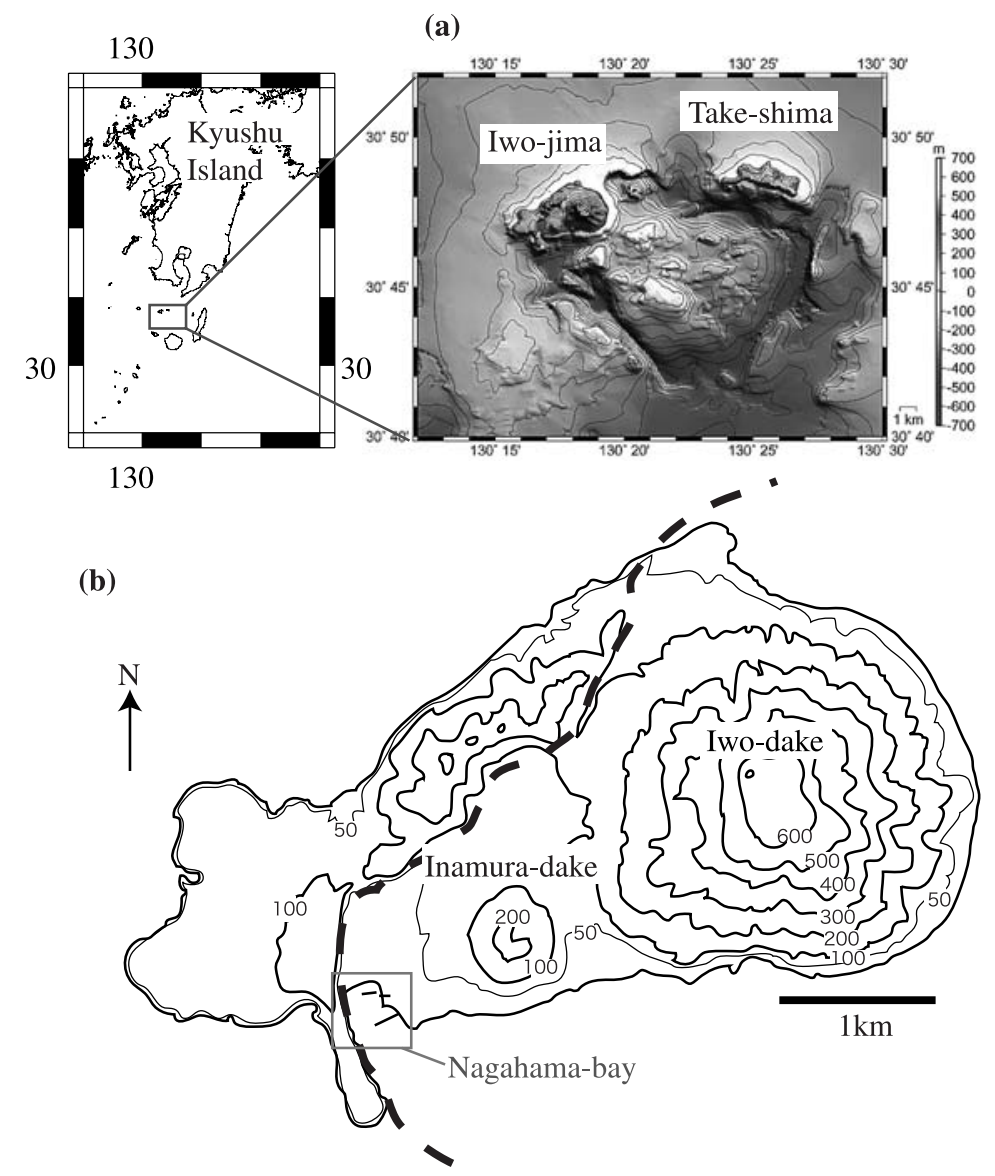

Fig. 1. Locality maps of (a) Submarine topography of Kikai Caldera (JCG, 2008), and (b) Satsuma Iwo-jima Island. The dashed line represents the rim of Kikai Caldera. 


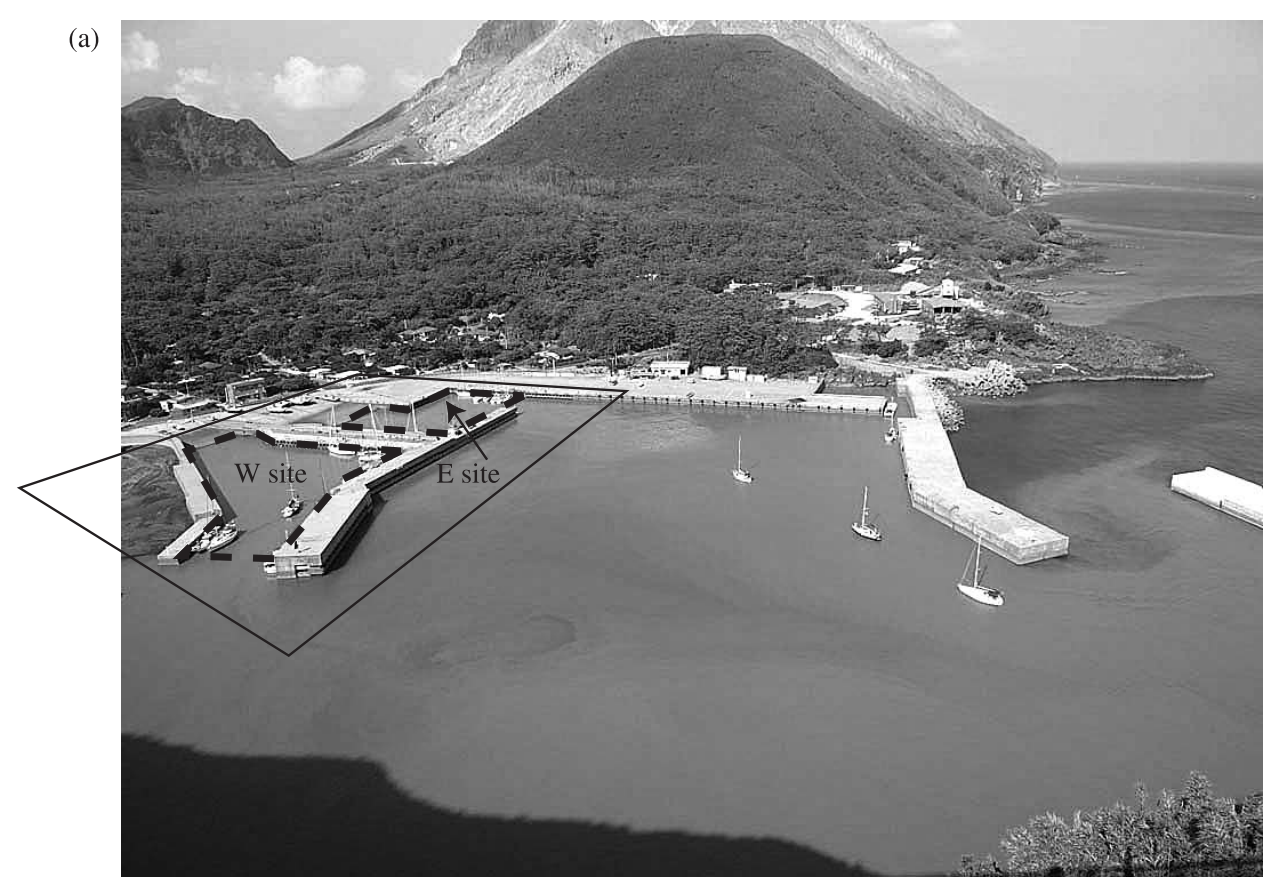

(b)

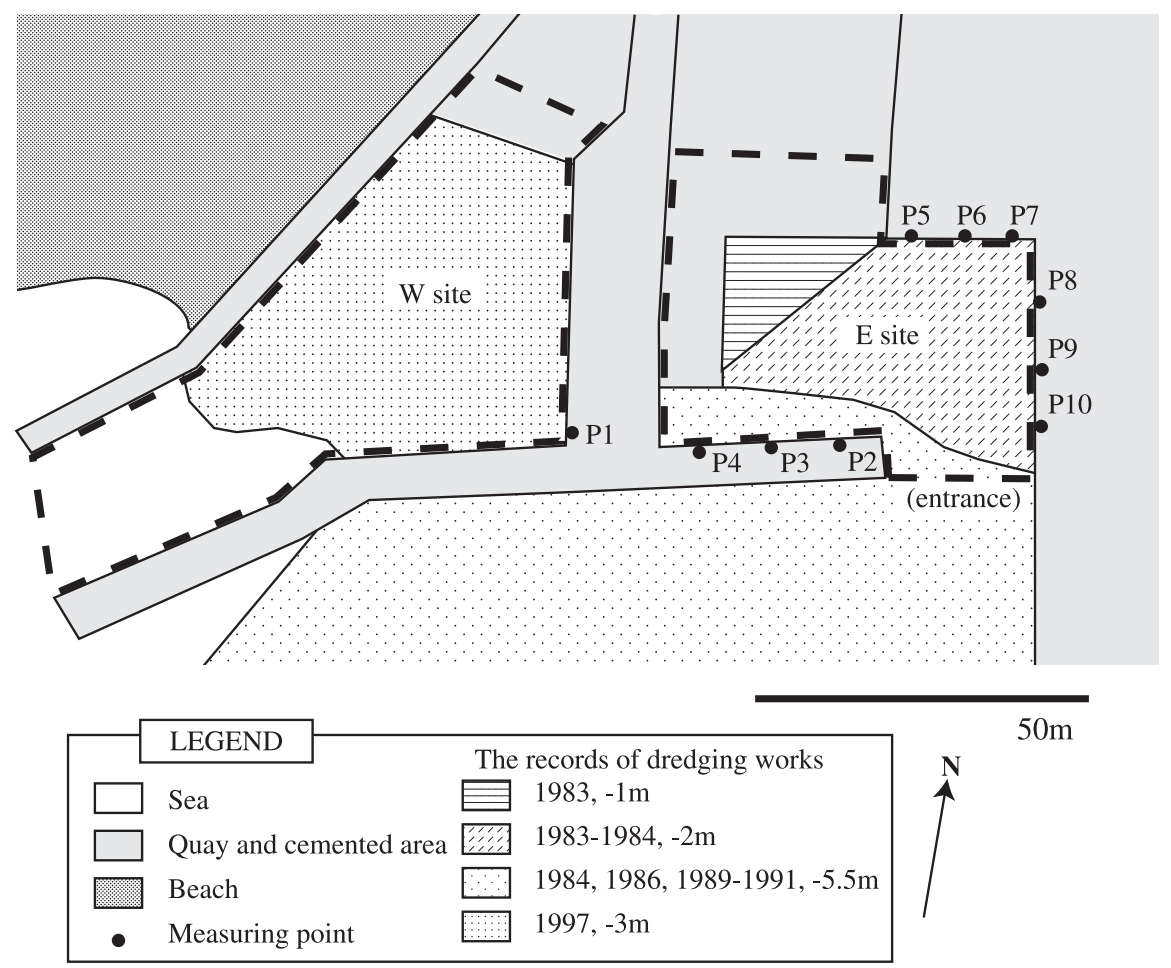

Fig. 2. (a) Overview of Nagahama Bay. The study area is shown by dashed lines. (b) The record of dredging at Sites E and W (Kagoshima Prefecture, 2007). The sampled sites for seawaters are shown as P1-10. 


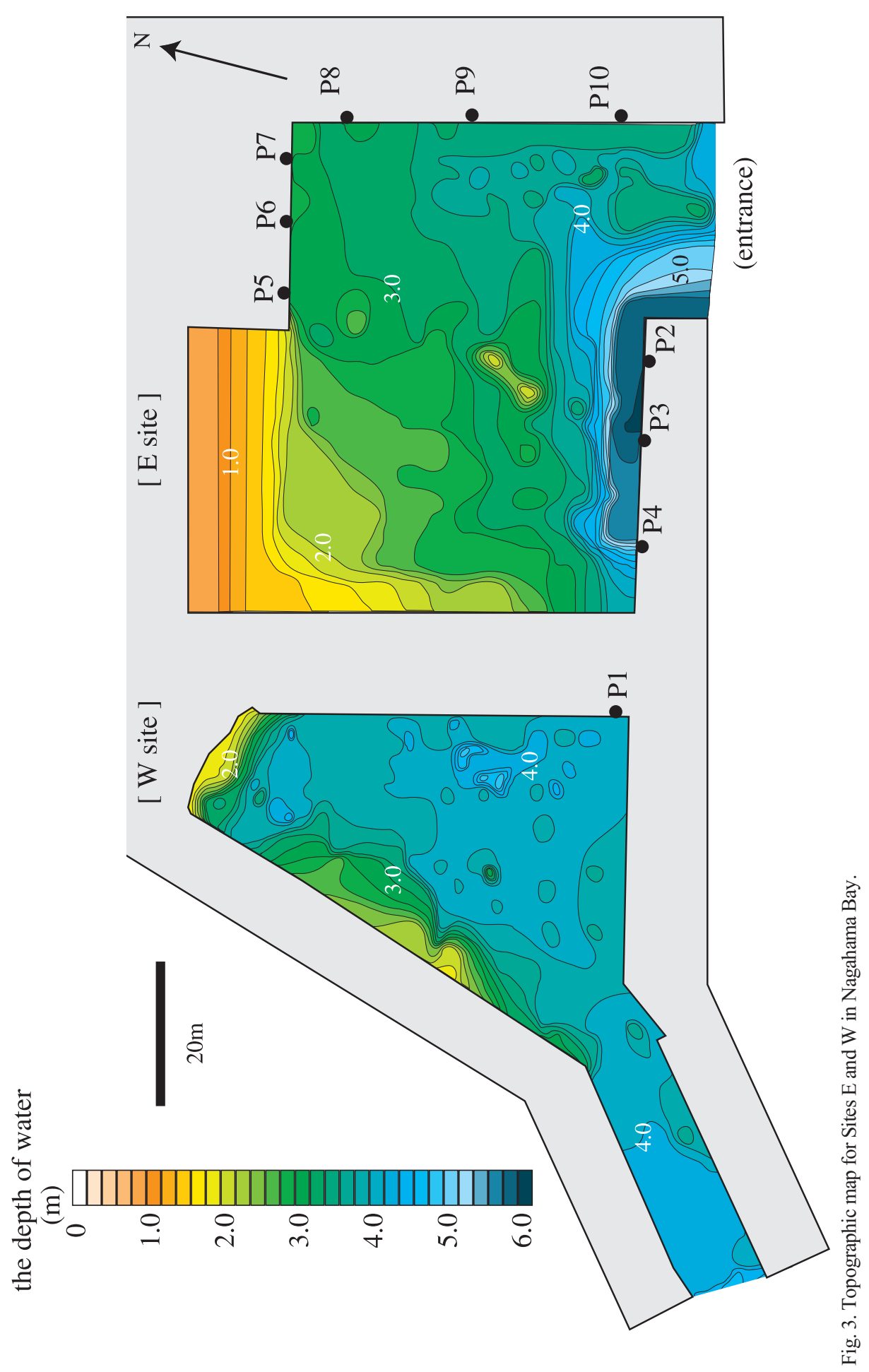


dake was 610-500 years B.P. (Kawanabe and Saito, 2002) and it is still active, with fumarolic gas which measured $902^{\circ} \mathrm{C}$ was present in the summit area in 1994 (Shinohara et al., 2002).

Hot springs around Satsuma Iwo-jima Island bear abundant aluminous and ferric ions (up to $1250 \mathrm{mg} \mathrm{l}^{-1}$ and $649 \mathrm{mg} \mathrm{l}^{-1}$, respectively). As they circulate along the coast of the island, the neutralization of the hot fluids and seawaters causes these ions to separate out as precipitates. The color of the seawaters turns to either ivory (aluminum-rich) or reddish brown (iron-rich). The seawaters are especially reddish brown within Nagahama Bay in the southwestern part of the island (Fig. 2). The hot-spring water represents $\mathrm{pH}$ value of 5 due to the presence of carbonic acid (Kamada, 1964). Microbial mats and a bio-terrace were reported in a small portion of this bay (Shikaura and Tasaki, 2001).

A part of the port is divided into two parts by the T-shaped breakwater; the square eastern area is "Site E" and the triangular western area is "Site W" (Fig. 2a). Nagahama Port was constructed by Kagoshima Prefecture during the multiple periods of 1952, 1959, 1977-1978, 1983-1991, 19931994, 1996-2004, and 2006-2007 (Fig. 2b). The record of dredging is shown in Fig. 2b. The dredging was undertaken five times at Site E and once at Site W. The water was much darker in color at Site E, compared to that at Site W.

\section{Topography in Nagahama Bay}

Topographic maps of Sites E and W are shown (Fig. 3). The depth of the sea floor was measured with a an eco-sounder (HONDEX PS-50C) from a small rubber raft (Achilles FMI-332).

The map shows the evidence of dredging activity (Fig. 2). While Site W represented a relatively flat floor, Site E represented gradually sloping floor towards the pelagic region. In a rectangular area on the south side of the site, the water depth was $6 \mathrm{~m}$. Mounds less than $1 \mathrm{~m}$ in height were characteristically present in the central area and around the entrance area of Site E.

\section{Methods}

Employing a multiple sensor (HORIBA WX-22), the seawaters were measured for $\mathrm{pH}$, turbidity, and depth at ten discrete locations, designated as P1 at Site W, and P2-10, from the proximal end of the bay entrance to distal end along the coast of Site E (Fig. 2). Data were collected every $50 \mathrm{~cm}$ from the surface to the bottom of the seawater column at all locations, and up to four times daily at high, ebb, low, and incoming tides, during the daytime for about two weeks (23 September -7 October 2007). We collected data automatically five times every 2 seconds at each depth. We used a tide table for Makurazaki, published by the Japan Meteorological Agency, for it is the nearest station to Iwo-jima Island. Cross sectional images of the turbidity data were drawn using ODV software (Schlitzer, 2008). The wave-height data were corrected with reference to ladder steps on the side of the dock.

\section{Results}

Tidal and wave effects on the reddish brown seawater are shown as cross sections based on turbidity data (Fig. 4). The turbidity was mainly related to the degree of discoloration of the seawaters, or to the density of suspended ferric particles. Stratification of the seawaters was present most of the time, and was shown as a decrease in turbidity from the surface to the bottom of the 

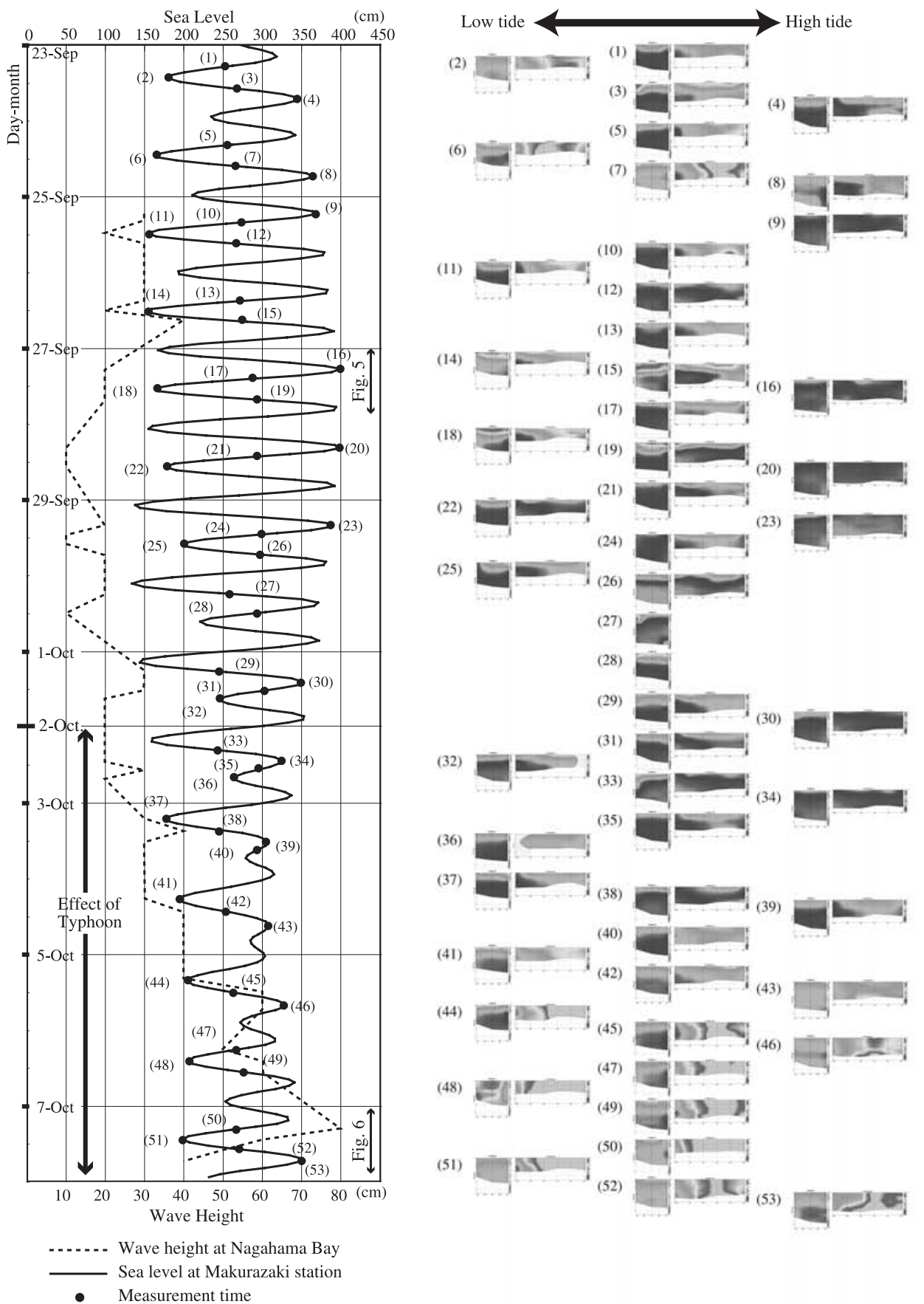

Fig. 4. Cross sectional images of turbidity along P2-4 (left) and P5-10 (right) from 23 September to 7 October 2007, using ODV software (Schlitzer, 2008). The color chart on the right side of each image shows the minimum zero value of NTU in purple and the maximum value of $120 \mathrm{NTU}$ in orange. The solid line is the mean tidal level at Makurazaki, $50 \mathrm{~km}$ away from Iwo-jima and the proximal station for the Metrological Agency tidal data; the dashed line represents wave height in Nagahama Bay. The numbers (1)-(53) in the graph correspond to cross sectional images. 
September 27 th, 2007
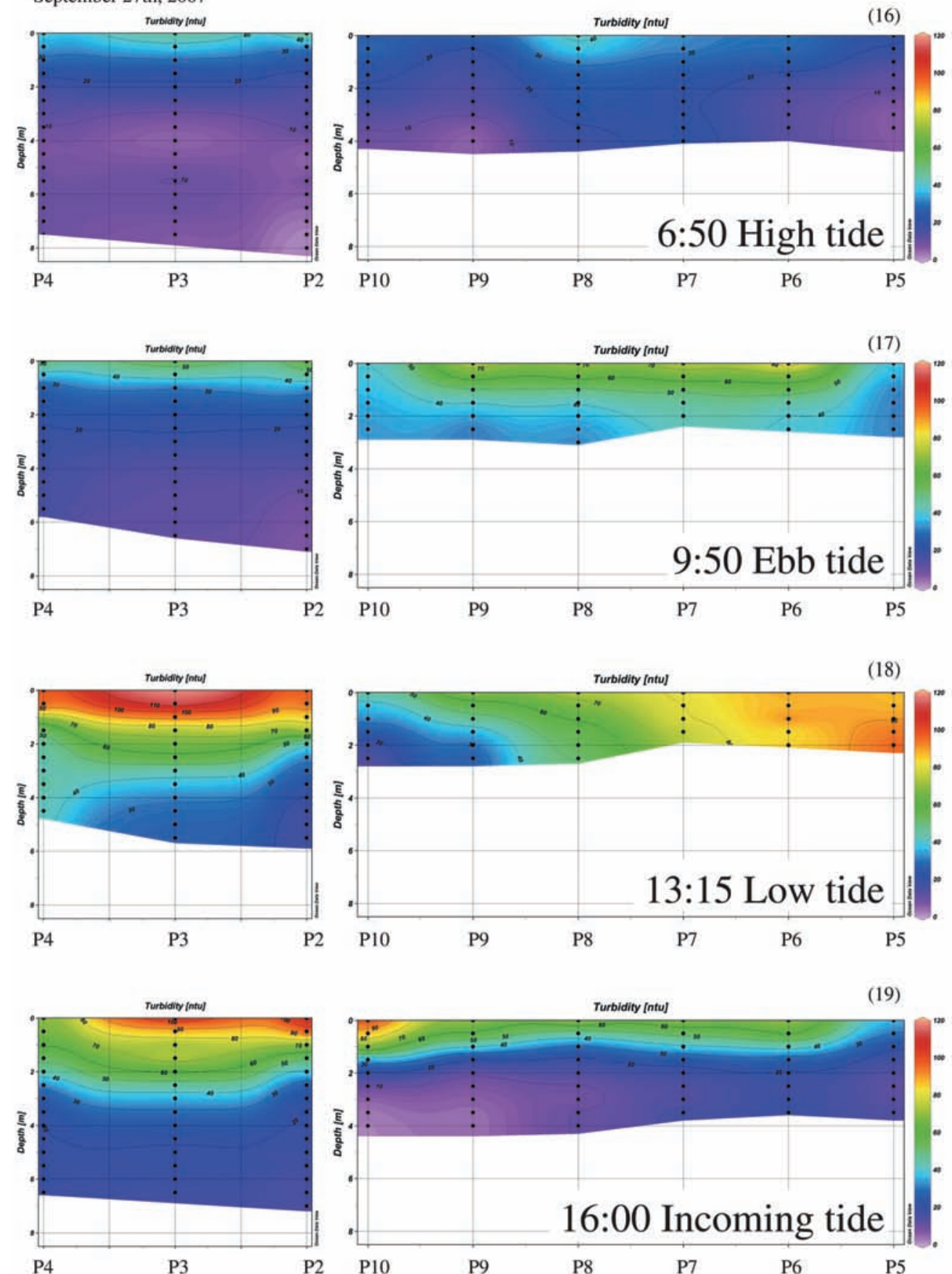

Fig. 5. Cross sectional images of turbidity (27 September 2007). They were derived in the same way as in Fig. 4. Black dots represents the measured datum points. 
October 7th, 2007
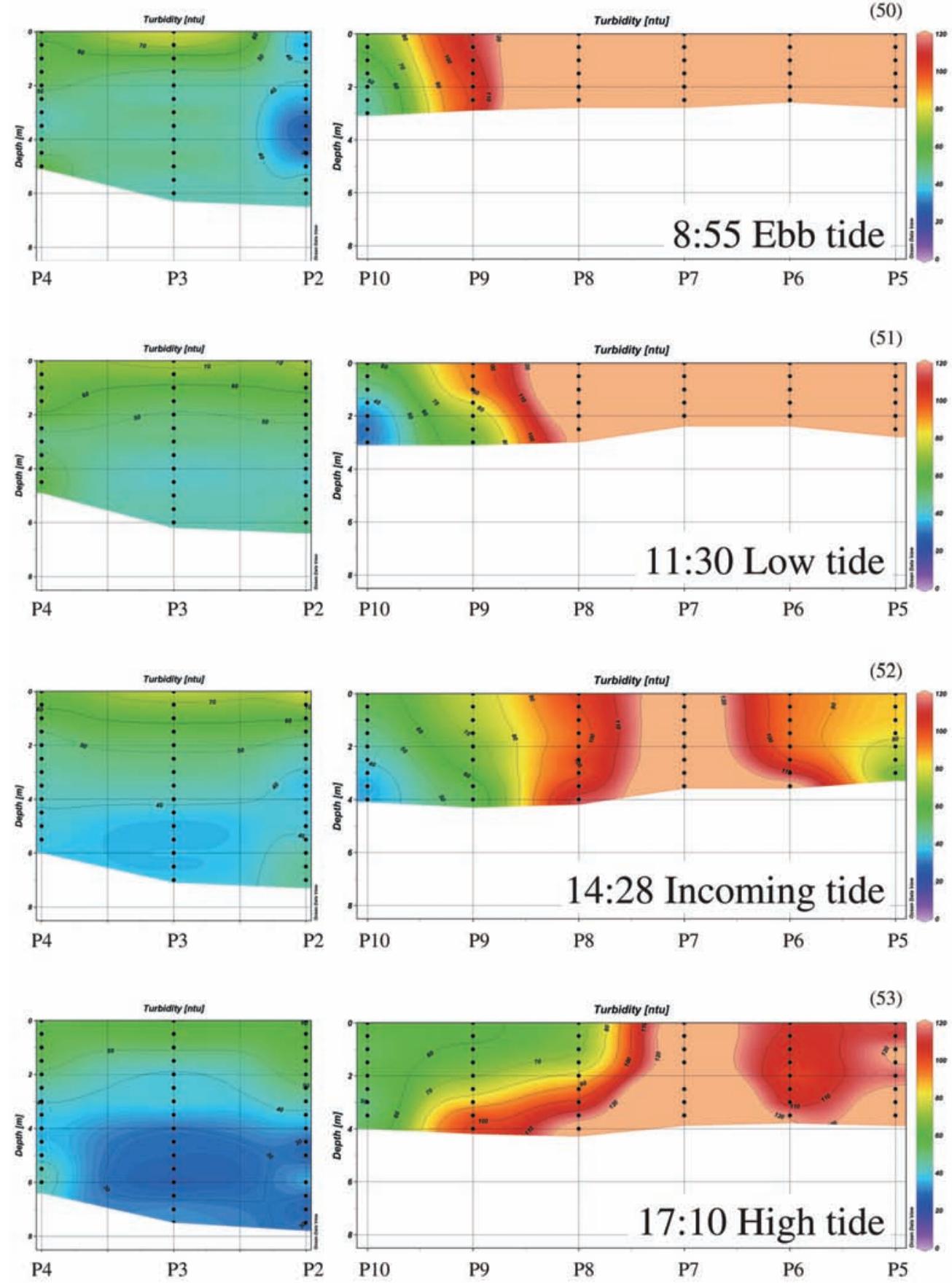

Fig. 6. Cross sectional images of turbidity (7 October 2007). They were drawn in the same way as in Fig. 4. 

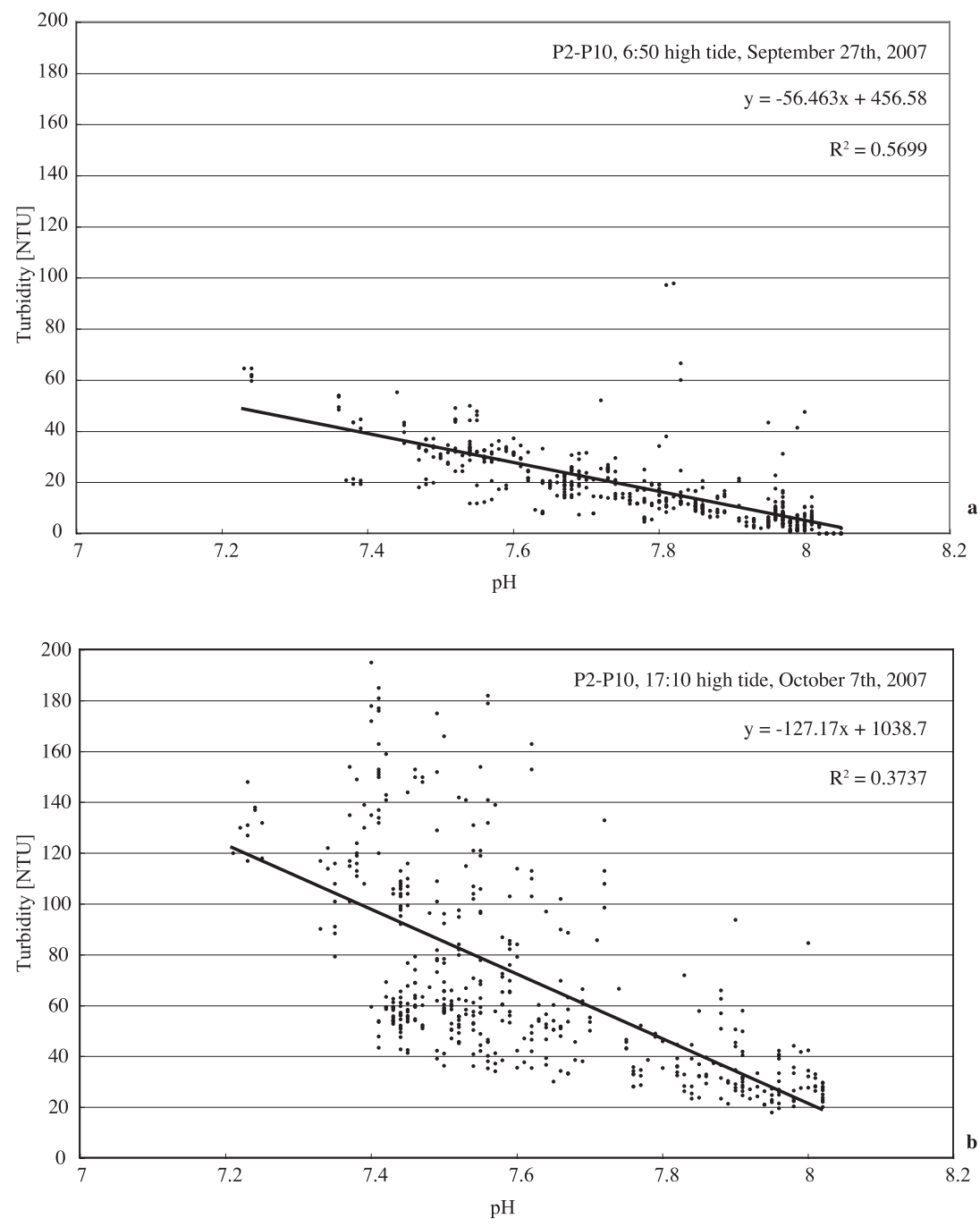

Fig.7. Illustrations showing the changes in $\mathrm{pH}$ and turbidity. The data are at high tide at $\mathrm{P} 2-10$ of (a) 27 September 2007, and (b) 7 October 2007. The lines in the graphs are linearizations of the data. The $\mathrm{R}^{2}$ values are coefficients of determination.

seawaters, and from the distal end to the proximal end by the entrance of the site.

\subsection{Tidal change}

Both daily and lunar tidal cycles affected the seawater colors. During the present study, the Full Moon was on 27 September and the New Moon on 3 October 2007. Focusing on the data for high tide, turbidity decreased from 23 to 29 September.

An extremely clear water with zero Nephelometric Turbidity Unit (NTU) value was found below the sea surface on 27 September (Fig. 5)-1 October, especially at P2, which had the maximum depth in all the locations. The data for 29 September showed the most wide spread occurrences of the clear zero NTU value waters, at the bottoms of P2, 8, 9, and 10. 
The daily data for 23 September (ebb, low, incoming, and high tides) during a neap tide exhibited turbidity ranges of 11-78 (ebb tide), 22-117 (low tide), 7-134 (incoming tide), and 6-160 NTU (high tide). On the other hand, data for 29 September (high, ebb, low, and incoming tides) during a spring tide exhibited ranges of 0-16 (high tide), 5-86 (ebb tide), 0-89 (low tide), and 0-87 NTU (incoming tide). On that day, the turbidity of zero NTU value occurred at P2, 8, 9, and 10 during high tide, at P10 during low tide, and at P2, 3, 4, 5, 9, and 10 during an incoming tide.

\subsection{The influence of a Typhoon}

With the onset of a Typhoon, the turbidity increased markedly for all seawaters, with values exceeding $120 \mathrm{NTU}$ (Fig. 6). At the same time, the maximum wave height was $80 \mathrm{~cm}$, which was higher than the values of 10-30 cm for usual days. According to the Meteorological Agency, a Typhoon occurred in the Philippine Sea, 2,000 km south of Satsuma Iwo-jima Island on 2 October. It moved to the northwest and on 7 October it was located on Taiwan, which was located some $1,200 \mathrm{~km}$ southwest of the study region.

The $\mathrm{pH}$ values were correlated to the turbidity (Fig. 7). On 27 September, a normal day, they were approximated by a linear function at 0.570 of the correlation coefficient. However, on 7 October, a stormy day, the correlation coefficient dropped down to 0.374 .

\section{Discussion}

The clear water mass from the pelagic region advected into the bay along the bottom, which attributed to the low turbidity at a deeper depth and at the sites proximal to the entrance. The illustration for sea-level change showed the maximum range on 29 September; the highest sea level was on the 27 and 28 September. Nevertheless, the cross section image for turbidity illustrates the clearest trend at high tide on 29 September. Therefore, the lunar cycle influenced the difference in sea level from high to low tides.

The daily change showed clear seawater masses at high tide and cloudy seawater masses at low tide. Comparing ebb tide to the incoming tide, the former led cloudier water than that by the latter, although both represented close to the mean depth of this area. This difference indicates a reduction of the ferric precipitates in the upper part of the seawaters, by means of the inflow of pelagic seawaters during incoming and low tides.

The high Typhoon waves kept the waters extremely cloudy all day; the influence of tides was overridden by the storm waves. As seen in the illustration for $\mathrm{pH}$ and turbidity, high turbidity or the density of suspending ferric precipitates was affected by the hot spring water of $\mathrm{pH} 5$ on a normal day. Its high correlation coefficient value shows an inverse correlation between $\mathrm{pH}$ and turbidity. A low correlation coefficient value was also found for the stormy day. The increase in turbidity was not necessarily due to a greater supply of ferric deposits from the $\mathrm{pH} 5$ hot spring water, but it was rather attributed to the resuspension of sediments due to the high energy storm waves. After the passing of the Typhoon, additional suspended ferric particles were expected to precipitate during the normal tide in the bay.

\section{Conclusions}

In this work, we examined two aspects of the seawaters in Nagahama Bay as follows. The inflow of clear waters from the pelagic region affected the density of suspended ferric precipitates. There were two cycles, comprising both diurnal and lunar cycle. The effect of the lunar cycles 
enhanced the clearness of the seawaters during high and spring tides. In particular, greater differences between low and high tides caused a decrease in deposition of suspended ferric matter. In a given day, high tide led the lowest density of ferric precipitates, followed by incoming tide, ebb tide, and low tide. Occasionally, high waves significantly increased the suspended ferric precipitates, which counteracted the influence of the tidal activity.

\section{Acknowledgements}

We thank Dr. Takashi Ito for constructive review of the manuscript, and Dr. Kazumasa Oguri, Kosei Yamaguchi, and Minoru Ikehara for discussions and thoughtful comments. We also thank the members of Mishima Village for their help in our field work. Prof. Hiroyoshi Sano, Dr. Takashi Sakai, and students in our laboratory helped us with great supports. This research was supported by Professor Tatsuro Matsumoto Scholarship Fund to the senior author, grants-in-aid of the Ministry of Education, Science, and Culture, Japan, 18654086 to the junior author.

\section{References}

Hydrographic and Oceanographic Department. (2008) Submarine Volcano around Satsuma-Iojima. Hydrographic and Oceanographic Department, Japan Coast Guard. Available online: $<$ http://www1.kaiho.mlit.go.jp/GIJUTSUKOKUSAI/kaiikiDB/kaiyo30-2.htm>,

Kagoshima Prefecture (2007) The plan of the renovation project of Iwo-jima Port. pp. 24.

Kamada, M. (1964) Volcano and geothermy of Iwo-jima, Kagoshima prefecture. Chinetsu, 3, 1-23 (in Japanese).

Kawanabe, Y., and Saito, G., (2002) Volcanic activity of the Satsuma-Iwojima area during the past 6,500 years. Earth Planets Space, 54, 295-301.

Matsumoto, T (1943) The four gigantic caldera volcanoes of Kyushu. Japan. Jour. Geol. Geogr., 19, $1-57$.

Ono, K., Soya, T., and Hosono, T. (1982) Geology of the Satsuma-Io-Jima district, Quadrangle series, scale 1:50,000, Tanegashima (16) No. 2. Geol. Surv. Japan, 1-80 (in Japanese with English abstract).

Schlitzer, R. (2008) Ocean Data View, http://odv.awi.de.

Shikaura, H., and Tazaki, K. (2001) Cementations of Sand Grains are Accelerated by Microbes Formation of bio-terrace at Satsuma Iwo-Jima Island. Clay Sci. Japan, 40(4), 229-241 (in Japanese with English abstract).

Shinohara, H., Kazahaya, K. Saito, G. Matsushima, N., and Kawanabe, Y. (2002) Degassing activity from Iwodake rhyolitic cone, Satsuma-Iwojima volcano, Japan: Formation of a new degassing vent, 1990-1999. Earth Planets Space, 54, 175-185.

Tarasov, V.G., Gebruk, A.V., Shulkin, V.M., Kamenev, G.M., Fadeev, V.I., Kosmynin, V.N., Malakhov, V.V., Starynin, D.A., and Obzhirov, A.I. (1999) Effect of shallow-water hydrothermal venting on the biota of Matsupi Harbour (Rabaul Caldera, New Britain Island, Papua New Guinea). Cont. Shelf Res. 19, 79-116.

Tarasov, V.G., Gebruk, A.V., Mironov, A.N., and Moskalev, L.I. (2005) Deep-sea and shallowwater hydrothermal vent communities: Two different phenomena? Chem. Geol., 224, 5-39. 


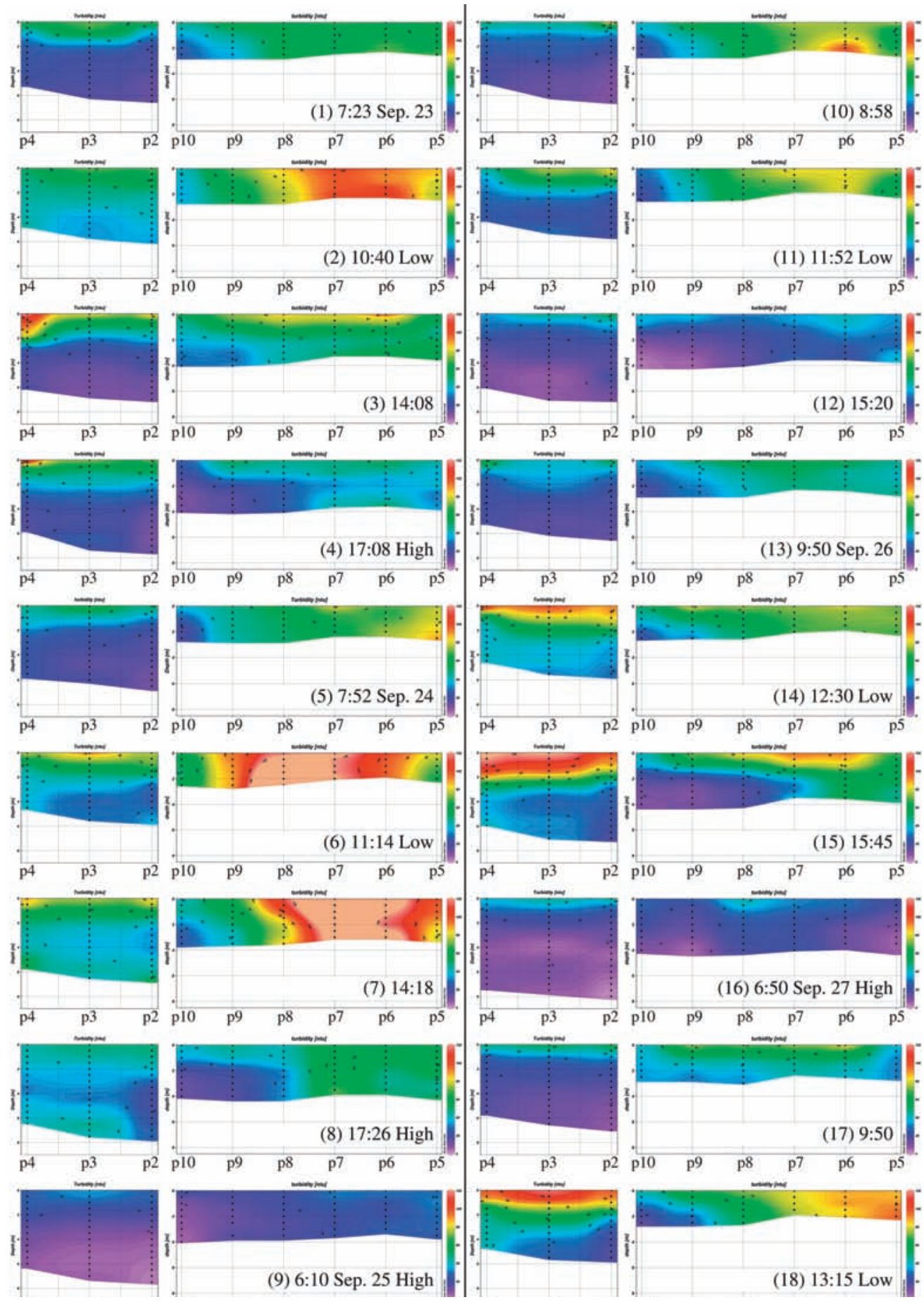

Appendix Fig. 1. All cross sectional images of turbidity along P2-4 and P5-10 at Site E in Nagahama Bay. 

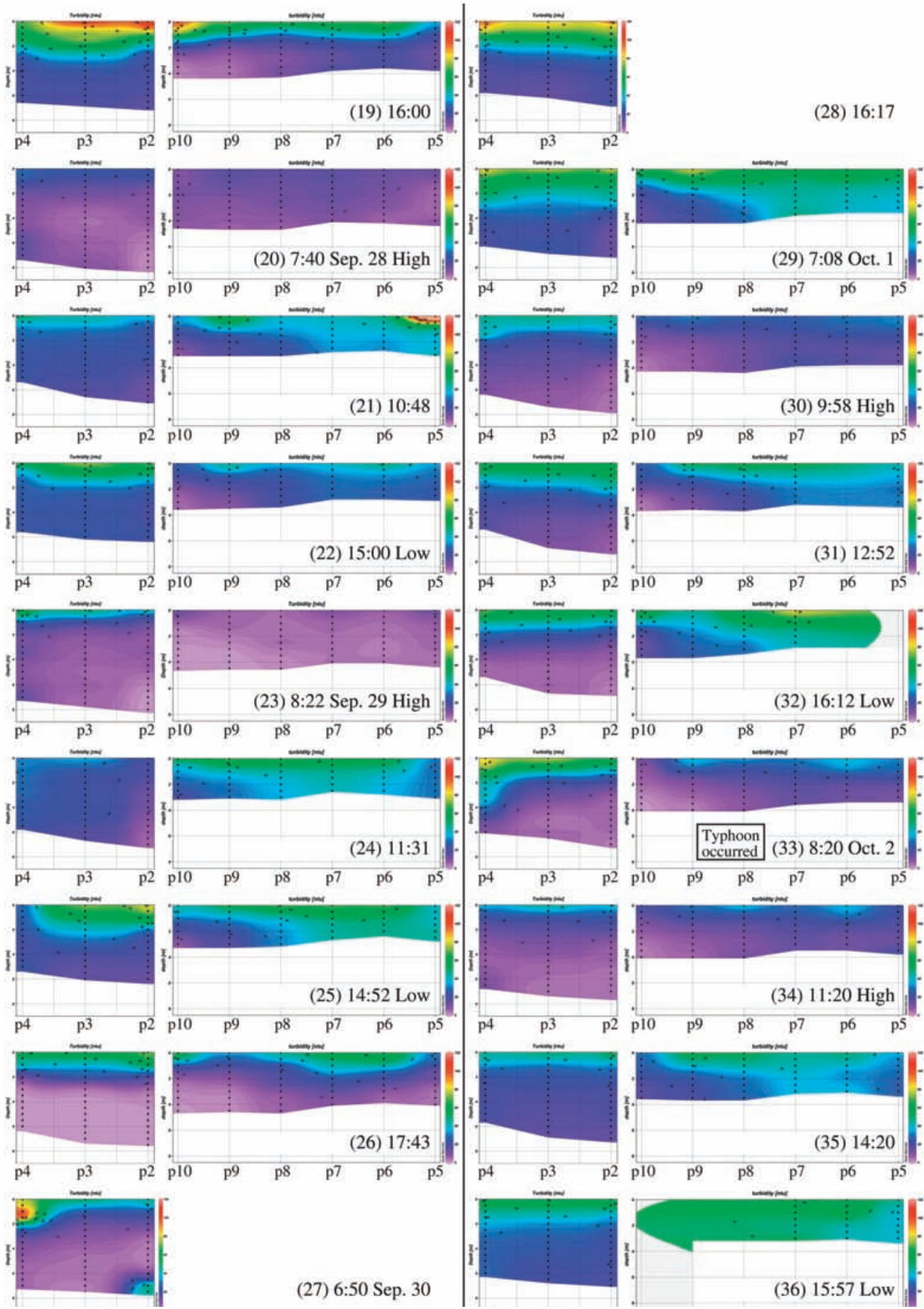


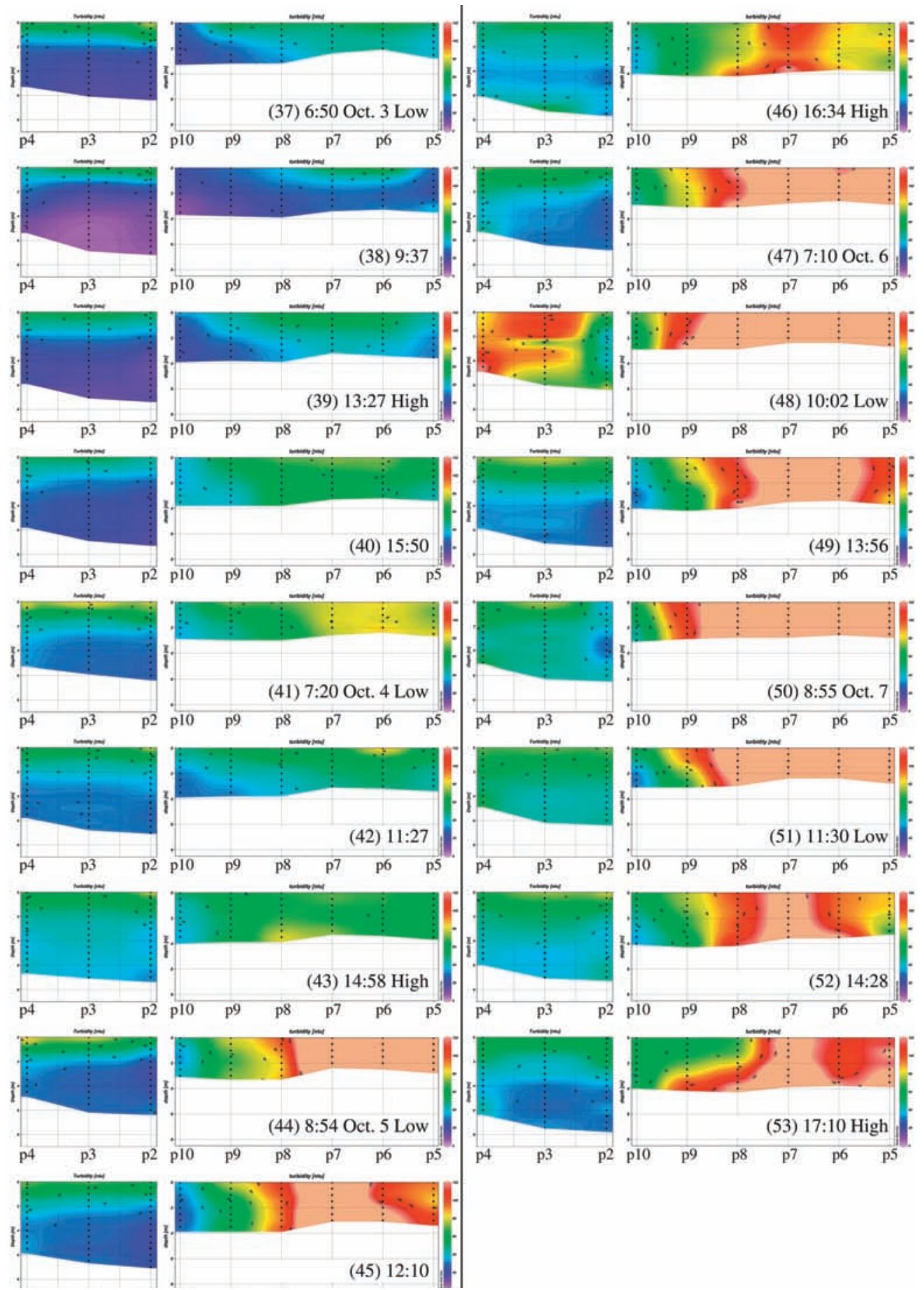

Appendix Fig. 1. (continued) 